\title{
THE EFFECT OF MARKET ORIENTATION AND INNOVATION ON COMPETITIVE ADVANTAGES
}

\author{
DOI: 10.17261/Pressacademia.2017.761 \\ RJBM-V.4-ISS.4-2017(10)-p.549-558
}

\section{Astrid Puspaningrum}

University of Brawijaya, Economics and Business Faculty, ,MT.Hariyono street 165 Malang, Indonesia. puspaningrumastrid@gmail.com

To cite this document

Pupaningrum, A., (2017). The effect of market orientation and innovation on competitive advantages. Research Journal of Business and Management (RJBM), V.4, Iss.4, p.549-558.

Permemant link to this document: http://doi.org/10.17261/Pressacademia.2017.761

Copyright: Published by PressAcademia and limited licenced re-use rights only.

\begin{abstract}
Purpose- Identify competitive advantages of embroidery SMEs embroidery from the aspect of market orientation and SME innovation. SME market orientation is applied from the ability of SMEs in finding market information to develop strategies and policies while SME Innovation from SMEs ability to apply technical innovation, product / service innovation and process innovation.

Methodology- Population of this research is the entrepreneurs and managers of SMEs embroidery in Pakis subdistrict Malang and Bangil subdistrict Pasuruan with a sample of 90 respondents. Analysis of the data in this study is done by using multiple regressions.

Findings- The results showed that the market orientation and innovation have a significant effect on competitive advantage. In order to gain a competitive advantage, then entrepreneurs and managers of small and medium enterprises (SMEs) embroidery in District Pakis Malang and Bangil Pasuruan develop marketing strategies by taking into account market orientation with the emphasis on the ability to monitor competitors and develop or doing innovations related to new products.

Conclusion, Market orientation affects the competitive advantage which is an indicator of competitor orientation and Innovation affects on the competitive advantage which is an indicator of technical innovation that are considered to have the largest or most powerful contribution as a reflection of the innovation variable.
\end{abstract}

Keywords: SME embroidery, market orientation, innovation and competitive advantage.

JEL Codes: C12,L26,M31

\section{INTRODUCTION}

The existence of Small and Medium Enterprises (SMEs) in East Java is very strategic in order to improve the economy. The strength of SMEs has proved as the net in the current economy in many large companies that have gone bankrupt. For the development of SMEs in East Java, it needs to get more serious attention in order to improve employers' ability to compete on regional and international markets. East Java governor stated that the existence of cooperatives and micro, small, and medium enterprises (SMEs) are able to absorb unemployment in the local region of the province. It is noted that the number of cooperatives and SMEs in East Java is not less than 30 thousand units. The number of workers is able to recruit as many as 97 percent of the total workforce in this province. Currently, total GDP revenues in East Java reached Rp1.135 trillion a year. The total revenues is 58.8 percent or Rp548,9 trillion comes from donations of cooperative sector and SMEs (www.antarajatim.com).

East Java has a craft industry center; one of the flagship products in East Java is the embroidery business. The embroidery industrial center is scattered in the area of East Java such as Surabaya, Malang, Kediri district, Pasuruan, Probolinggo, and Sidoarjo. The development of industrial centers in East Java border is still dominated by Pasuruan (Bangil) and Malang (Pakis subdistrict). In 2013, the number of small industrial embroidery business consisted of 236 units and the number of workers absorbed as many as 1248 workers (Disperindag, 2006-2013). Due to the expertise generated by generations and do not need higher education. It takes only tenacity, skill and creativity. But in 2006, the increase is very large which was $18.23 \%$ of the number of embroidery small industrial and the number of workers absorbed was $29.78 \%$ (Disperindag 20062013). This is because on September 11, 2005 the Government of Pasuruan stipulated that Bangil as the City of Embroidery (Embroidery Center). Therefore, many people flocked to establish their own business. 
As well as in District Bangil, Malang Regency society calls Sumberpasir Village at District Pakis as Embroidery Village. In the village, the embroidery activity has been done since 1975 ago. At that time, there were only 5 people. In the recent day, it has grown to 235 artisans. They are scattered in three hamlets out of four hamlets in the Sumberpasir village that is Krajan, Gagak Asinan, and Ngrangin. Embroidery artisans in the village are doing embroidery for various purposes such as the Muslim fashion, mukena, hijab, robes, a variety of souvenirs, table cover and sheets. In making embroidery, craftsmen used two ways which is manual sewing machines and hand embroidery. For products produced, there are semi-finished and finished. Such products are marketed to Malang, Surabaya, Jakarta, Bali, Lombok, Bengkulu, Borneo, Malaysia and Saudi Arabia.

In running a business, it can not be separated from competition between similar businesses, not least in the embroidery business in Sumberpasir subdistrict. The challenge facing entrepreneurs' embroidery business in Sumberpasir is very heavy. Apart from the regional embroidery entrepreneurs challenges also come from overseas products. This condition, if left then gradually small embroidery industry in Pakis Village subdistrict Sumberpasir will be worse off. It is a challenge for all parties concerned to find a solution to the growth of small industrial enterprises especially in Pakis village subdistrict Sumberpasir has not been afflicted by the encountered conditions.

Concerns will be increased due to high challenges faced by SMEs which can be seen from the difficulties of its SMEs to market their results. These conditions resulted in the decrease in sales volume that affect the inability of SMEs to increase employment even some SMEs which releases its workforce because they are not able to provide wages. With the pressure of a very tight competition, that directly or indirectly affects the performance of the company's organization in the apparel industry, including small and medium scale. Rapid changes in today, both in terms of technology, customer needs and product cycles getting shorter causing serious problems for the business world is no exception small and medium enterprises.

These circumstances make clear that it is necessary to know the factors that influence the competitive advantage of SMEs; this is done in order to compete to produce the products that the public interest such as Chinese and Korean goods. Besides, the internal factors of the majority of SMEs are lack of managerial capacity and skills, lack of access to information technology, capital and markets. This internal weakness due in part to lack of qualified human resources managers of SMEs in anticipating the problems being faced (Sugiarto, 2008).

Based on the various shortcomings above, it is required a special attention on the fate of the existence of SMEs as supporting the real economy society. Therefore, a tight competition requires companies to have a competitive advantage, otherwise the company can not survive. In an organization's competitive advantage can be gained by observing the superior value for customers, culture and climate to bring any improvement in efficiency and effectiveness. With advances in technology that can not be dammed, a product the company will add flourish to the point, where these products will be difficult to distinguish from one another. In order to win in a competition, then in marketing the current product manufacturers are not only based on product quality, but also relies on common strategies used by the company is a market orientation (Never and Slater, 1990) and innovation (Wahyono, 2002) as well as entrepreneurial orientation (Weerawerdena, 2003).

According to Kohli and Jaworski (1990), market orientation is a corporate culture that can lead to increased marketing performance. Never and Settler (1990), defined that market orientation as an organizational culture that is most effective and efficient to create behaviors that are needed to create superior value for buyers and generate superior performance for the company. Companies that have made the market orientation as the culture of the organization will be based on the need of external base, wishes and market demand as a basis for preparing a strategy for each business unit within the organization, and determine the success of the company.

Companies that implement market orientation has advantages in terms of customer knowledge and the excess can be used as a source for creating products that comply with the wishes and needs of customers. Dewi (2006) found no evidence of a significant positive effect between market orientations on competitive advantage. Zhou, et al (2009) showed that the greater the customer orientation, more and more companies were able to develop a competitive advantage based on innovation and market differentiation. Lings, lan and Greenley, Gordon (2009) concluded that there is a significant relationship between market orientation with external marketing success (market orientation performance, financial, and customer satisfaction). Suhendri (2009) showed that the orientation of the market, the quality of human resources and marketing areas management can create competitive advantage.

In addition to market orientation, innovation can also be used as a strategy to achieve competitive advantage. The main goal of innovation is to meet the market demand so that product innovation is one that can be used as a competitive advantage for the company (Wahyono, 2002). Customers generally want the product - an innovative product to their liking. For companies, success in innovation means that the company is a step further than its competitors. This requires companies to recognize ingenuity customer tastes so that innovation does ultimately is consistent with the wishes of its 
customers. Thus innovation - should be planned and carried out carefully. Dewi (2006) concluded that there is a positive and significant influence between product innovations for competitive advantage. Suliyanto (2011) showed that the orientation of learning has a positive effect on technical innovation and administrative innovation, technical innovation has positive effects on the competitive edge, but innovation administration has no positive effect on the competitive advantage.

Logical reason of this study is that SMEs in various regions have characteristics that are not the same, although in general they are not different profiles. Especially for this research, the identification and analysis of the variables that affect the competitive advantage of SMEs is very important. Results of this research can be the foundation to develop strategies and policies to encourage the growth of SMEs.

\section{THEORETICAL FRAMEWORK AND HYPOTHESIS DEVELOPMENT}

\subsection{Competitive Advantage}

The goal of strategies development and tactics is that the companies can compete in any situation, especially when economic and political conditions are less favorable. Therefore, the company should have a competitive advantage. Ferdinand (2000) stated that in a competitive market, the ability of the company resulting in performance, particularly financial performance, highly dependent on the degree of competitive advantage. To perpetuate its existence, the company's competitive advantage should also be sustainable, because basically the company wants to perpetuate its existence. Sustainable competitive advantage is the company's strategy to reach its final destination, the performance of which generates high profits. This means that sustainable competitive advantage is not an end, but a means to achieve the ultimate goal of the company, which is to increase the company's performance. Kotler and Armstrong (2003) defines the competitive advantage is an advantage against competitors gained by offering a lower value or by providing greater benefits because the price is higher.

From the above definition, a competitive advantage can be defined as a strategy that benefits from the company to work together to more effectively compete in the market place. Strategies must be designed to achieve continuous competitive advantage (sustainable competitive advantages) so that the company can dominate the market, old and new markets. With these advantages, it will encourage the acquisition of a higher return, higher growth, and increase the market value (Joel Litman, 2000).

A company occupies a position of competitive advantage is due to the comparative advantage in resources produces superior value at a lower cost. Competitive advantage can not be understood by looking at the company as a whole. Competitive advantage comes from a lot of different activities undertaken by the company to design, produce, market, deliver, and support its products.

Competitive advantage includes determining the position of an attempt to maximize the value capabilities that set it apart from competitors. A company occupies a position of competitive advantage is due to the comparative advantage in resources produces superior value at a lower cost. Competitive advantage comes from a lot of different activities undertaken by the company to design, produce, market, deliver, and support its products. Competitive advantage basically grows from values or benefits created by the company for its buyers. Customers generally prefer to buy products that have more value than desired or expected. However, that value will also be compared with the prices offered. Purchasing the product will occur if customers consider the price of a product in accordance with the value it offers.

Some of the indicators used to measure competitive advantage as expressed by Song and Parry (1997), Dewi (2006) and Supranoto (2009) stated that the uniqueness of the product, product quality and competitive prices. The uniqueness of the product is a unique product that combines the company's artistic value with customers' tastes. The quality of products is the quality of the design of the company's products. Meanwhile, the competitive pricing is the company's ability to adjust product prices with the general price in the market.

\subsection{Market Orientation}

Market orientation is something that is important for the company in line with increased global competition and changes in customer needs that companies realize that they must always be close to the market. Oreintasi market a business culture in which the organization is committed to continue to be creative in creating superior value for customers. Uncles (2000) defined that market orientation as a process and activities associated with the creation and satisfying customers by continually assess the needs and desires of customers.

The implementation of market orientation will bring improved performance for the company. Narver and slater (1995) stated that market orientation consists of three components: customer orientation, competitor orientation and interfunctional coordination. Customer orientation and competitor orientation including all activities involved in obtaining information about the buyer and its competitors on the target market and spread through the business, while the 
interfunctional coordination based on customer information as well as competitors and consists of a coordinated business ventures.

The concept of customer orientation can also be interpreted as a sufficient understanding of the target customer purchase in order to create superior value for buyers continuously. The understanding here includes an understanding of the entire value chain of buyers, both during and at the time of the latest development in the future. This effort can be achieved through the process of finding information about customers (Uncles, 2000). Based on this information, the company salesperson will understand who its potential customers, both now and in the future and what they want for now and the future.

From this description, it can be understood that the implementation of market orientation requires a company's ability to find a variety of market information that can be used as the basis for the company to do the next step or strategy. Oriented company competitors often seen as a company that has a strategy and understand how to obtain and share information about competitors, how to respond to the actions of competitors and also how the top management responds to competitors' strategies (Ferdinand, 2000).

Nerver and Slater (1995) stated that interfunctional coordination is the usefulness of a coordinated resource company in creating superior value for the targeted customers. Interfunctional coordination refers to particular aspects of the organizational structures that facilitate communication between different organizational functions. Interfunctional coordination based on the information of customers and competitors as well as consists of business alignment effort which typically involves a more of the marketing department, creating superior value for customers. Interfunctional coordination can enhance communication and exchange between all the functions of an organization that takes into account customers and competitors, as well as informing the latest market trends. It fosters both confidence and independence among separate functional units, which in turn give rise to a corporate environment that is more willing to accept a product that is completely new, based on customer needs.

Market orientation is very effective in gaining and maintaining a tight competitive which starts with the planning and coordination with all the parts that exist within the organization to satisfy the needs and desires of consumers. Therefore, market orientation should emphasize the importance of the analysis of the needs and wants of target markets more efficiently and effectively than with competitors in an effort to achieve competitive advantage. Market orientation is a corporate culture that puts the market as the key to survival. Therefore, in order to maintain the growth rate in the middle of the competition increasingly complex, the market must be managed with systematic efforts, by means of information and to recognize customer needs so that the products provide customer satisfaction. Besides, the market must be approached in a way to dig up information on the characteristics and background of the customer so that the anticipation of the market can be done in a proportional manner. The main market should be well served if the company's overall expectation responsively to customers and competitors in the market. Thus, the market-oriented companies will show a competitive advantage in the middle of the competition.

In this study, the indicator used to measure market orientation refers to the opinion of Slater \& Narver (1995) which is a customer orientation, the orientation of competition and coordination between functions.

\subsection{Innovation}

The existence of a clear link between innovation with the development of competitive advantage and profitability is above the average, many companies are interested in learning how to generate innovation and managing the innovation process effectively (Lengnick Hall, in Hitt, et al: 2005). In the industry, where the dynamic environment has become a fact of life, innovation is closely related to organizational effectiveness (Robbins, 2006).

However, it is not easi to give birth for innovative ideas, let alone implement it. Many factors influence the implementation of effective organizational innovation. Structural aspects, cultural and human resources are a characteristic that always arise when researchers studied an innovative organization (Robbins, 2006). What is said Robbins apparently supported by a comprehensive review on a question of innovation is an organic structure that positively affects innovation (Damanpour, 1991 in Salah 2008). This organizational structure is lower in vertical differentiation, formalization and centralization, organic organizations facilitate flexibility, customization and inter action of the cross that makes innovation easier application. In the organic structure also encourages communication between units high, for example there are committees, task forces, crossed team - functional and other mechanisms that facilitate interaction across departmental lines (Monge, et al.: 1992). Organizations are able to implement innovations if it is supported by organizational culture means innovative organizations tend to have a similar culture is a culture that encourages experimentation (Robbins, 2006). Foster creativity and apply it in the form of innovation in response to the demands and needs of the company or organization to survive a necessity in an era where business environments evolve, change and fluctuate with highly dynamic, complex and difficult to predict. However, efforts to foster and implement innovations are often not supported by 
the managers in the company. Therefore, managers required to support the process of innovation are having a transformational leadership Characteristic is inspiring and energy to others through intellectual stimulation (Robbins, 2006).According to Damanpour (1991), innovation is an introduction to equipment, systems, laws, products or services, new technological production process, a structure or administration of the new system, or a new planning program for the adoption of an organization. Meanwhile, the type of innovation is the behavior and the factors that determine the adoption of such innovations. Research Damapour (1991) classifies innovations into several types such as: administrative innovation, technical innovation, product/service innovation, process innovation, radical innovation, incremental innovation.Administrative innovation is related to the organizational structure and administrative processes that are not directly related to the basic activities of an organization and its work is directly related to the management of the organization. Technical innovation is related to technology products, services, and production processes. Product innovation is a new product or service that was introduced on the outside or because of market requirements. Innovation process is a new element introduced in a production company or service operations, input raw materials, specification of tasks, jobs and information, and equipment used for the production of a product or making services. Radical innovation is the product services which have not been available in the past, or in the form of a new system (new delivery system) for the product and services that already exist. Belonging to the first category are: (1) Major innovation, an innovation services that are completely new to the market (has never existed in the market). It is usually very driven by information and technologybased computers. (2) Start-up business, a new service in a market which is previously served (3) New service for the present market, new products offered to consumers who already exist, even though such services could have been provided by other organizations. Incremental innovation is changes to the product and services that already exist, which is rated as the development (improvement). These changes can include: (1) Service line extention, the improvements or the expansion of existing service lines (2) Service improvement is the changes in features of services offered. (3) Style changes, are simple changes that have an impact on perception, emotion, and customer attitudes. So, what happened is not a fundamental change in services, but only in appearance only. Radical innovation is done on a large scale, carried out by experts in their field and usually managed by the department of research and development. Radical innovation is often done in the manufacturing and financial services institutions. While incremental innovation is the process of adjusting and implementing small-scale improvements and innovations are accounting consultants, $R$ \& $D$ services, retail trade and restaurant (De Jong \& Den Hartog,: 2003). In this study, the indicators used to measure innovation refes to the opinion of Damapour (1991) that is technical innovation, product / service innovation and process innovation

\section{RESEARCH HYPOTHESIS}

\subsection{The Influence of Market Orientation on Competitive Advantage}

Companies that implement market orientation have advantages in terms of customer knowledge and the excess can be used as a source for creating products that comply with the wishes and needs of customers. Dewi (2006) found no evidence of a significant positive effect between market orientations on competitive advantage. Zhou, et al (2009) showed that the greater the customer orientation, more and more companies were able to develop a competitive advantage based on innovation and market differentiation. Lings, lan and Greenley, Gordon (2009) concluded that there is a significant relationship between market orientation with external marketing success (market orientation performance, financial, and customer satisfaction).Ratnawati (2017) the result of statistic test show that SMEs innovation will have a competitive advantage if SMEs always create innovation such as product innovation, process innovation and market innovation.

Based on the study above, it can be arranged hypothesis is as follows:

H1: Market orientation has a positive and significant impact on competitive advantage

\subsection{The influence of Organizational Innovation for Competitive Advantage}

Dewi (2006) concluded that there is a positive and significant influence between product innovation for competitive advantage. Suliyanto (2011) showed that the orientation of learning has a positive effect on technical innovation and administrative innovation, technical innovation has positive effects on the competitive edge, but innovation administration has no positive effect on the competitive advantage.

Based on the study above, it can be arranged hypothesis is as follows:

H2: organizational innovation has a significant positive effect on competitive advantage

\section{RESEARCH METHODS}

The purpose of this study outline was to examine the effect of market orientation and innovation for competitive advantage. It is intended to test several hypotheses have been proposed to study rests on a theory that has been built investigators. Therefore the type of research that is consistent with the objectives and the hypothesis is the study of causality. Causality research is research that want to find an explanation in the form of causal relationships (cause-effect) 
between multiple variables (Ferdinand, 2006). This study aimed to define the causal relationships between some of the situations described in the research model and on that basis then drawn a general conclusion. The hypothesis proposed in this study is a causality hypothesis.

This type of research conducted is also a survey research. Survey research is research that takes a sample of the population using questionnaires as the principal tool (Singarimbun: 1999). This method is also called questionaire method since to obtain such data are usually submitted a series of questions that are arranged in a list.

\subsection{Population and Sample}

The population in this study is the entrepreneurs and managers of SMEs embroidery in Pakis subdistrict Malang and Pasuruan Bangil. According to Djarwanto (1999), "The sample is part of the population whose characteristics is going to be investigated and is considered to represent the entire population or a number less than the total population. Roscoe in Sekaran (2006) stated that in the multivariate study (including multiple regression analysis), the sample size should be several times (preferably 10 times) of the number of variables in the study. Given the number of variables used in this study that is 3 variables, the number of samples used as much as $9 \times 10=90$ respondents from entrepreneurs and managers of small and medium enterprises (SMEs) embroidery in Pakis subdistrict Malang and Pasuruan Bangil.

\section{DATA ANALYSIS METHOD}

\subsection{Mulltiple Regression Analysis}

This method is used to see the effect oforgaizatiola learning, market orientatition and innovation on competitive advantage. The equatio model used I this study is:

$\mathrm{Y}=\mathrm{b}_{1} \mathrm{X}_{1}+\mathrm{b}_{2} \mathrm{X}_{2}$

Source : Sugiyono (2006)

Description:

$\mathrm{Y}=$ competitive advantage

$\mathrm{b}=$ Standardized Coefficient Beta

$\mathrm{X} 1=$ Market Orientation

$\mathrm{X} 2$ = Inovation

\subsection{Hipothesis Testing}

The hypothesis is to test the effects of market orientation and innovation on competitive advantage. Thie hypotesis is tested based on the t-value analysis which is gained from the multiple regression model. The mathematical formulation of the hypothesis is:

$\mathrm{H}_{0}: \beta=0, \quad$ market orietation and innovation have no significant effect on competitive advantage and $\mathrm{i}=1,2$

$H_{a}: \beta \neq 0, \quad$ market orientation and innovation have significant effect on competitive advantage and $i=1,2$

The significant level is $\alpha=5 \%$ and degree of freedom (k) and $(n-k)$ in which $n$ is the observation and observation number, then $k$ is the independent variable. Then, the $t_{\text {count }}$ is formulated as follow:

$t_{\text {count }}=\frac{\beta_{i}}{S_{e} \beta_{i}}$

Source : Sugiyono (2006)

In which :

$\beta_{\mathrm{i}} \quad=$ regression coefficiet

$\mathrm{S}_{\mathrm{e}} \beta_{\mathrm{i}} \quad=$ Standard error of regressio coefficient

The significant level is $\alpha=5 \%$, then is $t_{\text {count }}>t$ table then $H_{o}$ is rejected and $H_{a}$ is accepted or if the probality (Sig.) $t<5 \%$ then $\mathrm{H}_{\mathrm{o}}$ is rejected $n d \mathrm{H}_{\mathrm{a}}$ is accepted.

\section{FINDINGS AND DISCUSSION}

The multiple regression analysis method is used to see analisis whether or not there is the effect of market variable (X1), and innovation (X2) on competitive advantage (Y). the result of multiple linear regression analysis is done by using Statistical Package for Social Science (SPSS) 17.0 for windows which can bee seen on Table 1: 
Table 1: The Recapitulation of Multiple Regression Analysis

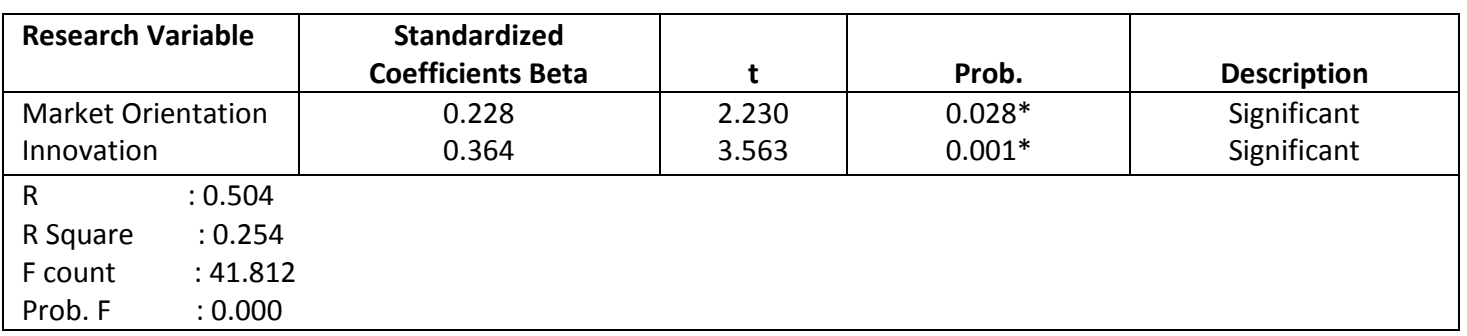

(*). Statistically significant at the level $\alpha=5 \%$

Table 1, explains that market orientation and innovation has a significant effect on competitive advantage at $5 \%$ statistics level. These results indicate that market orientation and innovation contribute to competitive advantage of $25.4 \%$, while the remaining $74.6 \%$ is influenced by other variables outside the model.

The final model of the overall multiple regression analysis shown in Figure 1 below:

Figure 1: Final Research Model

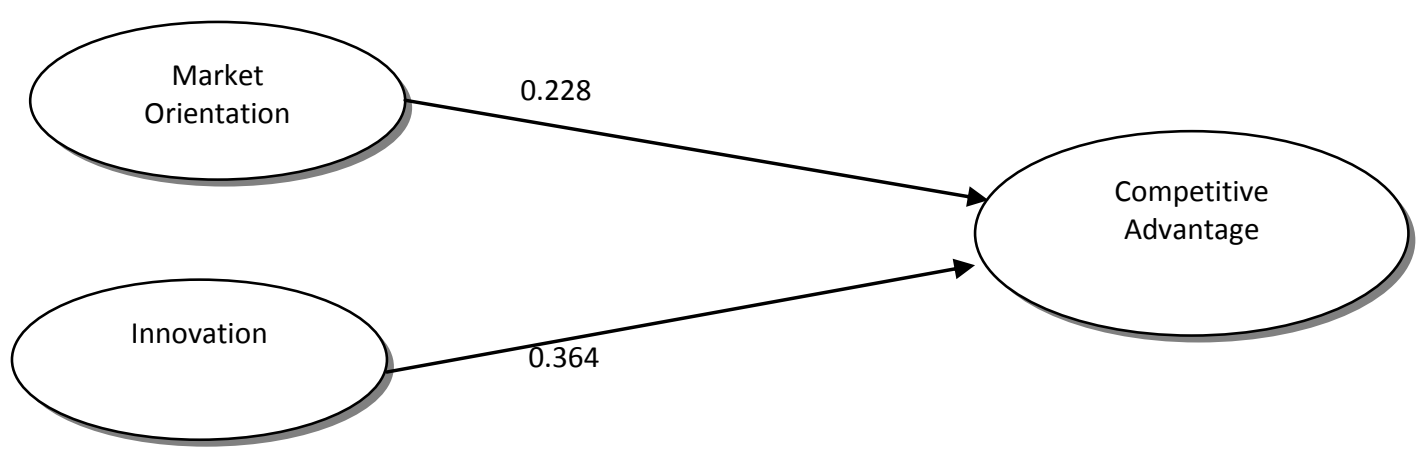

\subsection{The Effect of Market Orientation on Competitive Advantage}

Based on the results of inferential statistical analysis, it is found that the market orientation significantly influence competitive advantage. These results can be explained that the orientation of the market is something that is important for the company in line with increased global competition and changes in customer needs that companies realize that they must sealu close to its market. Market orientation is a business culture in which the organization is committed to continue to be creative in creating superior value for customers. Uncles (2000) defined that market orientation is a process and activities associated with the creation and satisfying customers by continually assess the needs and desires of customers. These results extend the study proposed by the Dewi (2006) which concluded that there is a significant positive effect between market orientation on competitive advantage. Zhou, et al (2009) showed that the greater the customer orientation, more and more companies were able to develop a competitive advantage based on innovation and market differentiation. Suhendri (2009) showed that the orientation of the market, the quality of human resources and marketing areas management can create competitive advantage.

\subsection{The Influence of Innovation on Competitive Advantage}

Based on the results of inferential statistical analysis, it is found that innovation significantly influence competitive advantage. According to Damanpour (1991), innovation is an introduction to equipment, systems, laws, products or services, new technological production process, a structure or administration of the new system, or a new planning program for the adoption of an organization. The contribution of innovation for competitive advantage, if it is associated with a descriptive analysis of the results, there is evidence that the indicators were considered to have the largest or most powerful contribution as a reflection of technical innovation is the innovation variable. Results of this analysis show that entrepreneurs and managers of small and medium enterprises (SMEs) embroidery in Pakis subdistrict Malang and Bangil Pasuruan need to develop or innovate with regard to products.

These results extend the study proposed by Dewi (2006) concluded that there is positive and significant correlation between innovation to excellence bersain. Suliyanto (2011) showed that the orientation of learning has a positive effect on 
technical innovation and administrative innovation, technical innovation has positive effects on the competitive, but innovation administration has no positive effect on the competitive advantage.

\section{RESEARCH IMPLICATIONS}

The implications of the research findings consist of two things which are the theoretical and practical implications.

\subsection{Theoretical Implications}

From the conducted research findings, it consistently shows that market orientation and innovation influence the competitive advantage. The implications can be explained as follows: The implications is associated with the effect of market orientation on competitive advantage is consistently expanding the study of the Dewi (2006) that there is a significant positive effect between market orientation on competitive advantage. Zhou, et al (2009) showed that the greater the customer orientation, more and more companies are able to develop a competitive advantage based on innovation and market differentiation. Suhendri (2009) showed that the orientation of the market, the quality of human resources and marketing areas management can create competitive advantage.

\subsection{Practical Implications}

The practical implications of this research are as follows: (a) Entrepreneurs and managers of small and medium enterprises (SMEs) embroidery in Pakis subdistrict Malang and Pasuruan Bangil need to streamline the programs that are used to meet customers' needs. (b) Entrepreneurs and managers of small and medium enterprises (SMEs) embroidery in Pakis subdistrict Malang and Bangil Pasuruan need to develop or innovate with regard to the product.

\subsection{Research Limitations}

In general, this research has tried to answer the formulation and research purposes, but there are limitations to this study such as: (1) The study has only been done on small and medium enterprises (SMEs) embroidery in Pakis subdistrict Malang and Bangil Pasuruan. Therefore, there is only an interpretation of the leader and have not been able to represent the condition of the entire small and medium enterprises (SMEs) embroidery in Pakis subdistrict Malang and Bangil Pasuruan. (2) The results of this study is the perception of the leader of small and medium enterprises (SMEs) embroidery at the time of data collection, thus, it can change any time for different circumstances, especially with regard to the studied variables.

\section{CONCLUSIONS AND SUGGESTIONS}

\subsection{Conclusion}

Market orientation affects the competitive advantage which is an indicator of competitor orientation which is considered to have the largest or most powerful contribution as a reflection of market orientation variable. These results can be explained that entrepreneurs and managers of small and medium enterprises (SMEs) embroidery in Pakis subdistrict Malang and Bangil Pasuruan will gain a competitive advantage if they will achieve competitive advantage. If the company has the ability to monitor competitor

Innovation affects on the competitive advantage which is an indicator of technical innovation that are considered to have the largest or most powerful contribution as a reflection of the innovation variable. These results can be explained that entrepreneurs and managers of small and medium enterprises (SMEs) embroidery in Pakis subdistrict Malang and Bangil Pasuruan will gain a competitive advantage if they are able to develop or innovate with regard to generate new products.

\subsection{Suggestion}

In order to gain a competitive advantage, then, entrepreneurs and managers of small and medium enterprises (SMEs) embroidery in Pakis subdistrict Malang and Bangil Pasuruan should develop marketing strategies through the following steps: (a) Embroidery entrepreneurs always pay attention on the orientation of the market by focusing on the ability to monitor competitors. (b) Developing or making innovation related to new products.

\section{ACKNOWLEDGEMENTS}

This article was supported by Faculty of Economics and Business University of Brawijaya Indonesia. 


\section{REFERENCES}

Amit, R. and P.J.H. Schoemaker. 1993. Strategic Assets and Organizational Rent, Strategic Management Journal, Vol.14, pp.33-46.

Arikunto, S. 2006. Prosedur Penelitian Suatu Pendekatan Praktek. Jakarta, PT. Rineka Cipta.

Barnes, James G. 2003. Secret Of Customer Relationship Manangement. Alih bahasa. Andreas Winardi. Yogyakarta : Penerbit Andi.

Barney, Jay.1991. Firm Resources and Sustained Competitive Advantage. Journal of Management, Vol. 17, No. I,pp.99-120

Chuang, S.H. 2004. A Resource-based view on Knowledge manufacturing Capability dan Competitive advantage: An Empirical Investigation. Expert Systems with Applications, 27, pp. 459-465.

Cleveland, J. and P. Plastrik, 1995. Learning, Learning Organization and TQM. In A.M. Hoffman and D.J. Julius (Eds), Total Quality Management: Implications for Higher Education, Maryville, MO: Prescott, pp. 233- 243.

Cunningham, J.B. and P. Gerrard, 2000. Characteristics of Well-Performing Organisations in Singapore, Singapore Management Review, Vol. 22, No.1, pp.35-64.

Damanpour F. 1991. Organizational innovation: a meta-analysis of effects of determinants and moderators. The Academy of Management Journal, Vol. 34, No. 3, pp. 555-590.

Dewi, Sensi Buana.2006. Analisis pengaruh orientasi pasar Dan inovasi produk Terhadap keunggulan bersaing Untuk meningkatkan kinerja pemasaran (Studi pada Industri Batik di Kota dan Kabupaten Pekalongan). Tesis, Program Studi Magister Manajemen Universitas Diponegoro

De Jong, J \& Hartog, D D.2003. Leadership as a determinant of innovative behaviour. Scientific AnaLysis of Entrepreneurship and SMEs. Pp. 1-77.

Farrell Mark Anthony,.2008. Market orientation, learning orientation and organisational performance in international joint ventures. Journal of Marketing and Logistics. Vol. 20 No. 3,2008. pp. 289-308

Ferdinand, Augusty.,2000. Manajemen Pemasaran:Sebuah pendekatan Strategy. Research Paper Series. No.01 Program Magister Manajemen Universitas Diponegoro

Ferdinand,Augusty.2006. Metode Penelitian Manajemen, pedoman penelitian untuk penulisan skripsi, tesis dan disertasi ilmu manajemen, Badan Penerbit Universitas Diponegoro

Grant, R.M.2002. Contemporary Strategic Analysis, 4th Ed., Oxford: Blackwell

Gujarati, D.2000. Essentials of Econometrics, International Editon, McGraw-Hill.

Hollensen Svend.2010. Marketing Management: A Relationship Approach, second edition, Pearson Education Limited.

Malhotra, N.K.2006. Marketing Research, London. Prentice Hall International Industri.

Monge, PR.,M.D.Cozzens \& NS.Contractor.1992. Communication and Motivational Predictors of the Dynamics of Organizational Innovation, Organization Science, 1, 135-148.

Njuguna, I. Jhon.2009. Strategic Positioning For Sustainable Competitive Advantage: An Organizational Learning Approach. Journal of Business Management: Vol. 2, Issue 1. pp. 32-43.

Penrose, E.T.1999. The Theory of the Growth of the Firm, 7rd Edition, New York: Oxford University Press.

Peteraf, M.A.1993. The Cornerstones of Competitive Advantage: a Resource-Based View, Strategic Management Journal, Vol.14, No. 3, pp.179-191.

Pitelis, Christos.2009. Edith Penrose's 'The Theory of the Growth of the Firm' Fifty Years Later. MPRA Munich Personal RePEc Archive, Paper No. 23180

Porter, M.E.2004. The Competitive Advantages of Nations, Harvard Business Review.

Porter, Michael, E.1993. Competitive Strategy. The Free Press. New York.

Ratnawati.2017. SME'S Innovation of The Mediator of The Influence of The Implementation of CSR Program on Competitive Advantage of SME's in Malang. Journal Of Applied Management.Vol.15,Issue 2,pp.261-270.

Robbins, S.P.2006. Perilaku Organisasi. Edisi Kesepuluh. Jakarta. Penerbit Erlangga.

Rogers, M, E. 1983. Diffusion of Inovations, The Free Press, NewYork.

Senge, P.M.1990. The Leader's New Work: Building Learning Organizations, Sloan Management Review, Fall 32 (1), pp.7-23.

Singarimbun, Masri.1999. Metode Penelitian Survai. Jakarta: LP3ES

Singarimbun, M dan Sofian E.2005. Metode Penelitian Survei. LP3ES, Jakarta. 
Sugiono. 2006. Metode Penelitian Administrasi. Alfabeta, Bandung:

Suliyanto. 2011. The Effect Of Orientation Learning On Competitive Advantage Through Innovation: Study On Small And Medium Enterprises. Business and Management Review, Vol. 1 (7) pp. $28-36$

Supranoto, Meike. 2009. Strategi menciptakan keunggulan Bersaing produk melalui orientasi pasar , Inovasi, dan orientasi kewirausahaan Dalam rangka meningkatkan kinerja Pemasaran (Studi empiris pada: Industri Pakaian Jadi Skala Kecil dan Menengah di kota Semarang). Tesis, Program Studi Magister Manajemen Universitas Diponegoro

Uncles, Mark. 2000. Market Orientation. Australian Journal of Management. Vol.25, No.2.pp. 1-15

Wang, Y. and H. Lo. 2003. Customer-focused Performance and the Dynamic Model for Competences Building and Leveraging: A Resourcebased View, Journal of Management Development, Vol.22, No.6, pp.483-526.

Wanto dan Ruswiati.2012. The Effect Of Organizational Culture And Organizational Learning Towards The Competitive Strategy And Company Performance (Case Study Of East Java Smes In Indonesia: Food And Beverage Industry). Information Management and Business Review, Vol. 4, No. 9, pp. 467-476

Wheelen, T.L. and J. David Hunger,2002. Strategic Management and Business Policy. Eighth Edition, New Jersey: Prentice-Hall.

Zhou. Kevin Zheng, James R. Brown, and Chekitan S. Dev.2009. Market orientation, competitive advantage, and performance: A demandbased perspective. Journal of Business Research, Vol. 62, Issue 11, pp. 1063-1070 